At first one would wonder what a military $m$ an might know about asepsis, and although there is little of professional instruction contained in the paper, $I$ infer that this Lieut. Col. for some reason or other ignores his professional title. This craze makes me tired, Doctor. Time was when the honorable title of doctor would be considered an honor for a prince. In point of fact, there is to day no more honorable title, and no good reason why physicians who respect their profession should be willing to exchange it for a complimentary military title.

I send you a communication received recently from the Secretary of War. For the sake of the profession and to put a damper on bombast and militarism in the usually dignified and modest profession of medicine, you may deem best to publish all of this. Sincerely yours,

W. Thornton Parker, M.D. Groveland, Mass, Jan. 26, 1896.

To the Honorable Secretary of War, Washington, $D$. $C$.

Sir:-I respectfully write for information concerning the commissions of medical officers in the United States Army.

In the U. S. Navy and in the Marine-Hospital Service, medical officers are known as surgeons, passed assistant surgeons, assistant surgeons, etc., and even in the armies of Europe, where the most radical system of militarism exists, under monarchial rule, medical officers are known as surgeons, assisttant surgeons, etc. But in our republican form of government, where the rights of citizenship are asserted to be preëminent, our surgeons have of recent years placed their medical titles in the background, and are addressed as captains, colonels, majors, lieutenants, etc.

While our forefathers warned us that one of the greatest dangers to the life of the Republic would be the development of military aristocracy, there seems to be in our little army of the present day a most extraordinary movement in this direction. In the medical corps of our army, which contains so many foreigners, a prominent medical officer who has enjoyed the exceptional rank and pay which our medical corps furnishes for many years, has only recently, if the report be correct, qualified as an American citizen.

I write this merely to ask if this system at present exist. ing in the medical corps of the U. S. Army has the approval of the Secretary of War and of the general officers of the U. S. Army. If it has I should like very much to know it and if it has not I should like to be able to answer foreigners who point at it as a grievous inconsistency in our republican institutions. Very respectfully yours,

W. T. PARKer, M. D.

(Brief.) Groveland, Mass., Jan. 26, 1896.

W. T. Parker, M.D., asks information as to commissions of medical officers U. S. Army. Says that in the Navy and Marine-Hospital Service medical officers are known as surgeons, passed assistant surgeons, etc., while in the Army they are addressed as lieutenants, captains, majors, colonels, etc., and asks if this system has the approval of the Secretary of War and general officers of the Army.

Second endorsement.

War Department, Surgeon-General's Office, Jan. 30, 1896.

Respectfully returned to the Honorable the Secretary of War.

Medical officers of the Army are commissioned as assistant surgeons with the rank of first lieutenant, assistant surgeons with the rank of captain, surgeons with the rank of major, deputy surgeons-general with the rank of lieutenant-colonel, and assistant surgeons-general with the rank of colonel. In all official communications they are addressed in accordance with these designations. It is customary in social intercourse to address medical officers by their professional titles, and in my judgment there is no objection to this form of address. Some of our medical officers, however, insist upon being called by their military title. This is in accordance with the usage in other staff corps. There seems to be no question as to the propriety of addressing a paymaster or a commissary or an adjutant-general by his military title; but in the case of a medical officer, upon whom the degree of doctor of medicine has been duly conferred, it would appear that in social and professional intercourse this title should have the preference.

Geo. M. Sternberg, Surgeon-General, U. S. Army.

Third endorsement.

War Department, Feb. 1, 1896.

Respectfully returned to W. T. Parker, M.D., Groveland, Mass., inviting attention to the preceding endorsement hereon of the Surgeon-General U. S. Army. Joseph B. DoE. Assistant Secretary of War.

\section{The Pneumatic Dilator.}

Philadelphia, May 21, 1896.

To the Editor:-My attention has just been called to a pas. sage in Dr. W. E. Owen's excellent paper on the "General and Special Treatment of Tuberculosis," in your issue of Jan. 11, 1896, which unintentionally of course upon Dr. Owen's part, is liable to be misconstrued into a recommendation by me of a certain instrument mentioned in the paper, Dr. Hawley's "pneumatic dilator." This apparatus may be capable of doing all that is said, but as I have never seen or used it, I can have no opinion about it specially worth expressing. The passage referred to is on page 67 and reads as follows: "By it [the aforesaid apparatus] the cardio-vascular and the pulmonary capacities are greatly increased, and to use the words of SolisCohen, 'resulting in increased function, increased elimination of waste products of function; with increased buoyancy of spirits which is no mean factor in treatment; in a word, heightened vitality.'" The remarks cited as from me (which, by the by, are not quoted verbatim et liberatim but slightly paraphrased) might, from the context, be thought to apply to the instrument exhibited by Dr. Owen. They are, however, a portion of my conclusions concerning the effect of altitude in stimulating nutrition in the prophylaxis or treatment of pulmonary tuberculosis, as may be seen by reference to page 789 of my article on Tuberculosis in Vol. I of "A System of Practical Therapeutics," edited by H. A. Hare, M.D., and published by Lea Bros. \& Co., Philadelphia, 1891, from which they are cited.

I have so often and so positively expressed myself in favor of the use of pneumatic measures, and especially the inhalation of compressed air with exhalation into rarefied air, in the prophylaxis and treatment of pulmonary tuberculosis, under suitable conditions and in proper subjects, that I should not like this correction to be misunderstood as opposing any proper method of securing pulmonary expansion by pneumatic devices, though theoretically I should think the usefulness of the instrument mentioned in Dr. Owen's paper to be rather limited, and should not wish the efficiency of pneumatic treatment in general to be judged by the results such an apparatus can probably produce. But, apart from this, I believe it better that words written in connection with one therapeutic measure should not be applied, without full explanation, to another.

I have been very much gratified to learn from various expressions in Dr. Owen's thoughtful article that the views concerning the causation and the proper treatment of tuberculosis and especially of pulmonary tuberculosis, which I have put forth in the work alluded to, have favorably impressed one so careful as an observer and so clear and forcible as a writer. The larger my experience becomes, the more firmly am I convinced that our great object in the prevention and in the therapeutics of this affection, should be to increase the vital, $i$. e., the resisting and recuperative powers of the organism in general and of the pulmonary tissues in particular. Neither drugs nor antitoxins can effect this. They may help, but they are secondary in importance. Very truly yours,

SOLOMON SOLIS-COHEN. 